\title{
PERENCANAAN STRATEGI BERSAING SEKOLAH DALAM MENINGKATKAN JUMLAH PESERTA DIDIK BARU DI SALAH SATU SEKOLAH SWASTA SALATIGA ${ }^{1}$
}

\author{
Dewa Made Dwi Kamayuda \\ Mahasiswa Program Pascasarjana Magister Manajemen Pendidikan \\ FKIP-Universitas Kristen Satya Wacana \\ dwikamayudadewa@gmail.com
}

\begin{abstract}
This study aimed to develop competitive strategy planning in increasing number of new students in one of private schools in Salatiga. The Design of the study is research \& development, but it is limited to the product design stage alone that produce schools competitive strategy planning in increasing the number of new students. Research instruments for gathering data are observation, interviews, FGD and study documents. Data Analysis used SWOT analysis to analyze the internal and external factors such as the school's strengths, weaknesses, opportunities and threats in determining the appropriate competitive strategies for schools. The result of SWOT analysis indicated that the school is in quadrant position SO (Strength Opportunity), which supports an aggressive strategy by using the power of the internal environment of the school to seize the opportunities from external environment. Competitive strategy planning of the school which suggested is differentiation strategy namely: making program "community service" in the form of "students service community", building cooperation and trust with the two primary schools under the same foundation, forming clubs academic achievement and non-academic, maximizing learning extracurricular through the program of "students exhibition" that can also be a program of "open house" of the school, maximizing the potential of teachers through seminars, training or workshops, maximizing the facility orphanage, making a jointly program of "parents \& students fun day", socializing to public and private schools, churches and Christian communities regularly.
\end{abstract}

Keywords: Competitive strategy, SWOT Analysis

\section{PENDAHULUAN}

\footnotetext{
${ }^{1}$ Naskah ini sudah pernah dimuat dalam Prosiding Seminar Nasional Membangun Budaya Penelitian untuk Meningkatkan Kualitas Pendidikan Indonesia Dalam Perspektif Revolusi Mental Guru di Indonesia yang diselenggarakan oleh Progdi S2 MMP-FKIP-UKSW tanggal 12 Maret 2016
} 
Persaingan antar sekolah yang terjadi sekarang ini begitu atraktif. Lembaga pendidikan yang merupakan penyedia jasa pendidikan berusaha untuk memikirkan bagaiamana cara yang tepat untuk meningkatkan kepuasan pelanggan serta memenuhi kebutuhan para pelanggan yaitu para siswa dengan meningkatkan mutu pendidikan di sekolah. Mutu pendidikan adalah gambaran dan karakteristik menyeluruh jasa pelayanan pendidikan secara internal ataupun ekternal yang menunjukkan kemampuannya memuaskan kebutuhan yang diharapkan (Sagala, 2010). Lebih lanjut Edward Sallis (2007) mengatakan bahwa manajemen mutu adalah sebuah filosofi tentang perbaikan secara terus menerus, yang dapat memberikan seperangkat alat praktis kepada setiap institusi pendidikan dalam memenuhi kebutuhan, keinginan dan harapan para pelanggannya, saat ini dan untuk masa yang akan datang. Oleh karena itu tiap sekolah perlu untuk terus meningkatkan kualitas pendidikan di sekolahnya melalui strategistrategi yang tepat demi tercapainya kepuasan siswa. Sesuai dengan yang dikatakan oleh Rahayu (2008) bahwa satuan pendidikan dituntut untuk senantiasa merevitalisasi strateginya, guna menjamin kesesuaian tuntutan lingkungan dan persaingan dengan kekuatan internal yang dimilikinya. Ketidakmampuan suatu satuan pendidikan dalam merespon peluang dan ancaman eksternal, akan mengakibatkan menurunnya daya saing atau terhambatnya pencapaian kinerja satuan pendidikan. Jika hal ini dibiarkan, maka akan mengancam kelangsungan satuan pendidikan yang bersangkutan.

Porter (2007) mengungkapkan bahwa salah satu strategi yang dapat dirancang oleh sekolah untuk menjaga dan meningkatkan daya saing sekolah adalah melalui strategi bersaing. Strategi bersaing merupakan upaya mencari posisi bersaing yang menguntungkan dalam suatu arena fundamental dimana persaingan berlangsung. Hal ini berarti setiap organisasi atau perusahaan perlu merumuskan strategi dan posisi yang tepat agar dapat memenangkan persaingan. Lebih lanjut Porter menjelaskan bahwa tujuan dari strategi bersaing adalah untuk membina posisi dimana suatu lembaga dapat melindungi diri sendiri dengan sebaik-baiknya terhadap kekuatan tekanan persaingan atau dapat mempengaruhi tekanan tersebut secara positif. Sehingga untuk menciptakan posisi bertahan yang aman (defendable position) diperlukan adanya strategi bersaing yang efektif yang mencakup tindakan-tindakan menyerang (ofensif) ataupun bertahan (defensive). Oleh karena itu penyelidikan dan analisis sumber masing-masing kekuatan adalah kunci untuk mengembangkan sebuah strategi.

Terdapat tiga pendekatan strategi generik yang secara potensial dapat berhasil mengungguli para pesaing dalam suatu bidang untuk menghadapi kondisi persaingan, 
yaitu keunggulan biaya menyeluruh, diferensiasi dan fokus (Porter, 2007). Strategi generik merupakan suatu pendekatan yang memungkinkan suatu lembaga untuk mendapatkan keunggulan kompetitif yang melebihi pesaing lainnya dalam suatu lingkup usaha (David, 2008). Oleh karena itu, setiap sekolah harus mampu mengembangkan keunggulan bersaing yang tidak mudah diimitasi oleh para pesaing lain. Keunggulan bersaing tersebut dapat diciptakan melalui efisiensi, kualitas produk, dan inovasi (Wijaya, 2008)

Memiliki posisi berbiaya rendah akan membuat suatu lembaga memperoleh hasil di atas rata-rata dalam bidangnya meskipun ada kekuatan persaingan yang besar. Posisi biaya memberikan kepada suatu lembaga ketahanan terhadap rivalitas dari para pesaing, karena biayanya yang lebih rendah memungkinkannya untuk tetap dapat menghasilkan laba setelah para pesaingnya mengorbankan laba mereka demi persaingan (Porter, 2007).

Dalam konteks lembaga pendidikan, keunggulan biaya yaitu strategi sekolah dalam mengefisienkan seluruh biaya operasionalnya sehingga menghasilkan jasa yang bisa dijual lebih murah dibandingkan pesaingnya. Strategi keunggulan biaya ini berfokus pada harga, sehingga pada umumnya sekolah tidak memperhatikan berbagai faktor pendukung dari jasa ataupun harga. Hal utama bagi pihak sekolah adalah menawarkan jasa dengan harga yang sangat bersaing (Wijaya, 2008). Akan tetapi, dalam menjalankan strategi ini setiap sekolah perlu menetapkan harga yang paling tepat sehingga dapat memberikan keuntungan, baik untuk jangka pendek maupun untuk jangka panjang (Lubis, 2004).

Strategi generik yang kedua adalah diferensiasi. Diferensiasi yaitu strategi suatu lembaga dalam memberikan penawaran yang berbeda dibandingkan dengan penawaran yang diberikan pesaing (Porter, 1992). Dalam konteks lembaga pendidikan, sekolah berusaha untuk menjadi unik dalam bidangnya dengan sejumlah dimensi tertentu yang secara umum dihargai pelanggan. Dasar pemikiran strategi diferensiasi menuntut sekolah untuk memilih atribut, mempunyai jasa yang berkualitas ataupun fungsi yang bisa membedakan dirinya dari para pesaing. Misalnya persepsi terhadap keunggulan kerja, inovasi produk, pelayanan yang lebih baik, citra merek yang lebih unggul dan sebagainya (Wijaya 2008).

Purwanto (2011) mengemukakan bahwa faktor-faktor yang menyebabkan keberhasilan sekolah dalam strategi diferensiasi meliputi; kurikulum dan program pendidikan, fasilitas, kemudahan akses, proses pendidikan, layanan dan paska layanan pendidikan. Semakin banyak aspek yang dimiliki tentunya akan memperkuat struktur 
lembaga pendidikan secara maksimal. Meskipun dalam mencapai diferensiasi akan berarti mengorbankan posisi biaya jika kegiatan yang dilaksanakan cukup mahal, tetapi dengan melakukan diferensiasi akan membuat lembaga tersebut memberikan dan menciptakan sesuatu yang bernilai (Porter, 2007). Itulah alasan untuk membayar sebuah produk atau jasa dengan harga yang tinggi. Harga tinggi untuk sebuah produk yang ditawarkan menunjukkan bahwa produk tersebut sangat bernilai dan dapat menjadi sebuah bentuk keunggulan kualitas bagi produk itu sendiri (Trout dan Rivkin, 2001). Oleh karena itu, setiap sekolah harus mencari cara melakukan diferensiasi untuk memungkinkan sekolah tersebut terus unggul, mendapatkan kesetiaan dari pelanggan, mendapatkan hasil yang lebih besar daripada biaya diferensiasi dan juga mencegah para pesaing mengembangkan cara untuk meniru hal unik yang ditawarkan secara tepat (David, 2008).

Ada beberapa hal yang perlu diperhatikan dan diterapkan oleh sekolah dalam menggunakan strategi diferensiasi, yaitu sekolah harus memiliki guru dengan tingkat kreatifitas yang tinggi, fokus sekolah jangka panjang, kerjasama yang tinggi di antara guru, perilaku guru yang saling melengkapi, perhatian guru yang cukup terhadap kualitas dan kuantitas pendidikan, adanya keseimbangan antara hasil pendidikan dengan proses pendidikan, dan memiliki toleransi tinggi terhadap ketidakpastian kondisi di sekolahnya. Hal ini bertujuan agar sekolah dapat menikmati hasil dari usaha yang telah dilakukan dan sekolah benar-benar dianggap unik (Wijaya, 2009)

Strategi generik yang ketiga adalah fokus. Strategi fokus dilakukan dengan memilih suatu bagian atau kelompok bagian tertentu dan menyesuaikan strateginya untuk melayani bagian atau kelompok segmen ini secara khusus. Dengan mengoptimumkan strateginya untuk segmen target yang dipilih, suatu lembaga fokus berupaya mencapai keunggulan bersaing dalam segmen targetnya walaupun tidak memiliki keunggulan bersaing secara menyeluruh (Porter 1992). Strategi fokus yang berhasil bergantung pada suatu lembaga yang memiliki potensi pertumbuhan yang bagus dan lembaga tersebut tidak memikirkan akan keberhasilan pesaing lainnya. Melalui penerapan strategi fokus yang berhasil, suatu lembaga dapat memperoleh keunggulan bersaing dalam target konsumen yang dipilihnya walaupun ia tidak memiliki keunggulan bersaing tingkat yang luas (Hitt dkk, 1997)

Dalam lembaga pendidikan, fokus yaitu strategi sekolah dalam menggarap satu target pasar tertentu. Hal ini pada umunya diawali dengan penentuan pangsa pasar oleh lembaga pendidikan. Di masyarakat sendiri, terdapat tiga kelompok utama secara 
ekonomi yaitu kelompok masyarakat tidak mampu, kelompok masyarakat menengah dan kelompok masyarakat mampu. Dalam melakukan penentuan pangsa pasar berdasarkan tiga kelompok utama masyarakat tersebut, lembaga pendidikan akan memilih dengan melihat juga pada kondisi sekolah itu sendiri termasuk dana pendidikan yang diperlukan (Purwanto, 2011)

Lebih lanjut Wijaya (2008) mengemukakan bahwa strategi fokus biasanya juga dilakukan untuk jasa yang memang mempunyai karakteristik khusus. Misalnya, Sekolah Kristen yang hanya ditargetkan bagi siswa Kristiani sehingga semuanya disesuaikan dengan ajaran agama Kristiani meskipun tidak menutup kemungkinan untuk siswa yang beragama lainnnya. Hal yang terpenting ialah fokus utama yang telah ditentukan sebelumnya dari sebuah lembaga pendidikan dapat terlaksana.

Dalam menentukan strategi bersaing diperlukan keunggulan yang tidak mudah diimitasi oleh pesaing, oleh karena itu sekolah harus dapat mengembangkan dan menciptakan keunggulan bersaingnya melalui efisiensi, kualitas produk dan inovasi (Wijaya, 2008). Selain itu sekolah juga perlu memperhatikan kriteria-kriteria dalam menampilkan sebuah keunggulan sekolah, diantaranya adalah; (1) Penting, artinya keunggulan itu harus merupakan kemampuan yang dianggap sangat penting oleh cukup banyak pembeli (2) Berbeda, artinya belum ada kompetitor yang menawarkan/memosikan keunggulan itu atau ada kompetitor yang sudah menawarkan, tetapi masih dengan cara yang lebih umum (3) Unggul (superior), artinya keunggulan itu lebih baik dibandingkan dengan produk barang atau jasa lainnya yang dimiliki kompetitor (4) Dapat dikomunikasikan, yaitu keunggulan itu dapat dikomunikasikan dan menjadi perhatian pembeli atau calon pembeli (5) Pelopor, artinya sulit meniru keunggulan yang dimiliki (6) Harga terjangkau yang berarti bahwa pembeli mampu membayar biaya keunggulan yang ditambahkan dalam produk tersebut (7) Menguntungkan yaitu perusahaan dapat memperoleh laba dari pemberian keunggulan tersebut (Kotler dalam Lupioyadi, 2013)

Permasalahan mengenai strategi bersaing ini dialami oleh salah satu sekolah swasta di salatiga dimana tiap tahunnya jumlah peserta didik baru yang mendaftar sangat sedikit bahkan kuota dalam kelas sangat jauh dari standar pelayanan minimal yang ditentukan oleh pemerintah melalui Keputusan Menteri Pendidikan Nasional Republik Indonesia Nomor 129a/U/2004 dalam Bab III pasal 3 yang menyebutkan bahwa jumlah siswa SMP/MTs per kelas berkisar antara 30 - 40 siswa. 


\begin{tabular}{|c|c|c|c|}
\hline No. & Tahun Pelajaran & Jumlah Rombel & Jumlah Siswa Baru \\
\hline 1 & $2011 / 2012$ & 1 & 6 \\
\hline 2 & $2012 / 2013$ & 1 & 13 \\
\hline 3 & $2013 / 2014$ & 1 & 15 \\
\hline 4 & $2014 / 2015$ & 1 & 12 \\
\hline 5 & $2015 / 2016$ & 1 & 17 \\
\hline
\end{tabular}

Tabel 1. Jumlah Peserta Didik Tahun 2011/2012 - 2015/2016

Dari data pada tabel di atas diketahui bahwa jumlah peserta didik baru sangat jauh dari standar yang diinginkan dan jika terus dibiarkan dapat mengancam keberadaan sekolah tersebut. Oleh karena itu melalui penelitian ini, penulis tertarik melakukan penelitian "Perencanaan Strategi Bersaing Sekolah Dalam Meningkatkan Jumlah Peserta Didik Baru Di Salah Satu Sekolah Swasta Salatiga" untuk membantu sekolah khususnya kepala sekolah dan para stakehoders yang ada untuk dapat menerapkan strategi-strategi bersaing dalam meningkatkan mutu sekolah, khususnya dalam meningkatkan kuantitas peserta didik baru di tahun-tahun berikutnya.

\section{METODE}

Penelitian ini merupakan penelitian dan pengembangan atau Research and Development (R \& D) dari Borg \& Gall (1983) yang dilaksanakan dengan tujuan untuk menghasilkan perencanaan strategi bersaing sekolah untuk meningkatkan jumlah peserta didik baru. Data dikumpulkan melalui observasi, wawancara, FGD dan studi dokumentasi. Teknik analisis data yang digunakan dalam penelitian ini yaitu analisi SWOT. Selanjutnya teknik yang digunakan adalah analisis matrik IFAS (Internal Factors Analysis Summary), analisis matrik EFAS (External Factors Analysis Summary) dan analisis matrik SWOT (Strengths, Weaknesses, Opportunities and Threats)

Dalam penelitian ini dibatasi sampai mendesain produk saja yaitu berupa perencanaan strategi bersaing sekolah. Langkah-langkah pengembangan ini dapat dilihat sebagaimana gambar berikut:

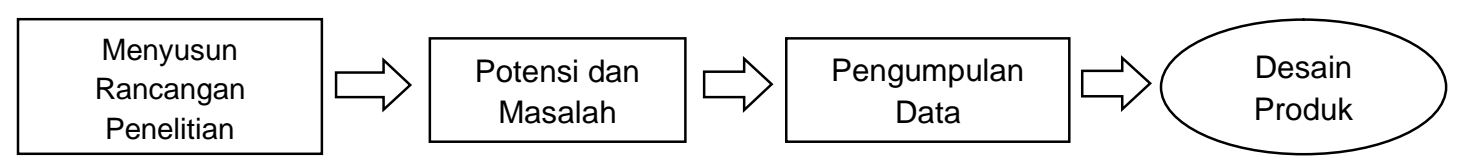




\section{Gambar 1. Langkah-langkah Penelitian Pengembangan}

Pada tahap awal peneliti melakukan persiapan sebelum melakukan penelitian yaitu melakukan observasi untuk meminta izin kepada kepala sekolah, melihat kondisi fisik sekolah dan mengenali lingkungan sekolah. Kemudian peneliti membuat instrumen penelitian berupa panduan wawancara dan panduan FGD. Tahap selanjutnya adalah pelaksanaan dimana peneliti melakukan wawancara kepada kepala sekolah dan guru untuk mengenali potensi dan masalah yang terjadi. Kemudian tahap berikut peneliti melakukan pengumpulan data melalui studi dokumen dan FGD lalu mendesain produk bedasarkan hasil analisis data dengan menggunakan analisis SWOT untuk mendesain perencanaan strategi bersaing bagi Sekolah.

Analisis data yang digunakan dalam penelitian ini adalah analisis SWOT yaitu dengan menggunakan teknik analisis matrik IFAS (Internal Factor Analysis Summary) dan analisis matrik EFAS (External Factor Analysis Summary) dan analisis matrik SWOT (Strengths Weaknesses Opportunities Threats). Adapun langkah-langkah dalam analisis SWOT adalah: (1) Mengidentifikasi faktor-faktor yang menjadi kekuatan, kelemahan, peluang dan ancaman yang dihadapai oleh sekolah; (2) Menentukan faktorfaktor yang menjadi kekuatan, kelemahan, peluang dan ancaman yang dihadapi oleh sekolah untuk meningkatkan mutu; (3) Memberikan bobot masing-masing faktor berdasarkan tingkat kepentingannya mulai dari 1,0 (sangat penting) sampai dengan 0,0 (tidak penting). Faktor-faktor tersebut kemungkinan memberi dampak terhadap faktor strategies; (4) Menghitung skor untuk masing-masing faktor dengan memberikan skala mulai dari 4 (outstanding) sampai dengan 1 (poor) berdasarkan pengaruh faktor tersebut terhadap konsisi sekolah yang bersangkutan. Pemberian nilai skor untuk faktor kekuatan atau peluang bersifaat positif (kekuatan dan peluang yang semakin besar diberi skor 4, tetapi jika kekuatan atau peluang kecil diberi skor 1). Pemberian skor kelemahan atau ancaman adalah kebalikannya. Jika nilai kelemahan atau ancaman sangat besar maka diberikan skor 1. Sebaliknya, jika kelemahan atau ancaman sedikit diberi skor 4; (5) Menghitung total skor dengan mengalikan bobot dan skor untuk masing-masing faktor kekuatan, kelemahan, peluang dan ancaman (Rangkuti F, 2013).

\section{HASIL DAN PEMBAHASAN}

Sekolah ini berdiri pada tahun 1949 dengan sebuah Visi sekolah yaitu Membentuk manusia “beriman, santun, cerdas dan terampil menuju kemandirian”. Untuk 
menggenapi visi tersebut, maka dirancanglah Misi sekolah yaitu: (1) Mengembangkan relegiusitas kehidupan siswa; (2) Mengembangkan pergaulan yang sukses dengan terampil menggunakan kata: Terimakasih, Tolong, Maaf, Selamat dengan tepat; (3) Menyelenggarakan KBM dan bimbingan secara kreatif dan efektif dan menyenangkan untuk mengembangkan potensi akademik dan non akademik; (4) Membiasakan siswa disiplin dalam memanfaatkan waktu, sarana dan prasarana sekolah; (5) Mengembangkan budaya menabung dalam rangka membentuk sikap hemat dan efisien.

Dalam rangka mencapai visi dan misi tersebut, sekolah menetapkan tujuan jangka pendek dan jangka menengah. Tujuan Sekolah jangka Pendek adalah: (1) Mengembangkan budaya relegiusitas melalui kegiatan keagamaan; (2) Mengembangkan pendidikan berkarakter kebangsaan melalui proses pembelajaran dan pembiasaan; (3) Melaksanaakn pembelajaran dan bimbingan secara aktif, kreatif dan menyenangkan; (4) Lulus ujian $100 \%$ pada ujian sekolah dan mencapai rata-rata nilai UN 6,0 pada tahun 2015/2016; (5) Mencapai kriteria ketuntasan minimal belajar siswa; (6) Mencapai prestasi akademik dan non akademik tingkat kota; (7) Melakukan kerjasama dengan berbagai pihak dalam melaksanakan program sekolah; (8) Menciptakan budaya tertib, ramah, bersih, hemat dan indah.

Selanjutnya tujuan jangka panjang sekolah adalah: (1)Terwujudnya suasana kehidupan sekolah yang beakhlak mulia dan berkarakter kebangsaan; (2) Tercapainya pembelajaran dan bimbingan secara aktif, efektif dan efisien; (3) Terwujudnya semangat berkompetensi secara intensif pada seluruh warga sekolah; (4) Tercapainya prestasi akademik dan non akademik pada tingkat kota dan provinsi; (5) Memiliki jumlah 2 rombongan belajar pada setiap tingkat kelas.

Sekolah ini memiliki 15 orang guru yang terdiri dari 7 guru laki-laki dan 8 guru perempuan. Terdapat 1 guru bergelar Master (S2), 12 guru bergelar sarjana (S1), 1 guru bergelar D2 dan 1 guru lulusan SMK Diklat. Selain itu sekolah juga didukung dengan 1 orang tata usaha, 1 orang pekarya.

Analisis SWOT dilakukan dengan mengidentifikasi faktor kekuatan, kelemahan, peluang dan ancaman melalui FGD kemudian di analisis dengan menggunakan tabel matrik IFAS (Internal Factors Analysis Summary) dan matrik EFAS (eksternal Factors Analysis Summary). Hasil analisis faktor lingkungan internal dan eksternal sekolah kemudian diberi bobot dan skor serta dilakukan perhitungan skor akhir dan diperoleh skor akhir IFAS (kekuatan - kelemahan) dan skor akhir EFAS (peluang - ancaman). Selanjutnya hasil analisis ini akan menunjukkan berada pada posisis manakah kondisi 
sekolah, apakah kuadran SO (Strength Opportunity), Kuadran ST (Strength Threat), Kuadran WO (Weakness Opportunity) atau Kuadran WT (Weakness Threat). Hasil analisis faktor kekuatan dan kelemahan hingga diperoleh matrik IFAS (Internal Factors Analysis Summary) dapat dilihat pada tabel 2 berikut :

Tabel 2. Hasil Analisis Faktor Kekuatan dan Kelemahan Matrik IFAS (Internal Factors Analysis Summary)

\begin{tabular}{|c|l|c|c|c|}
\hline \multirow{2}{*}{ No. } & \multicolumn{1}{|c|}{ Faktor-faktor Internal } & Bobot & Skor & $\begin{array}{c}\text { Total } \\
\text { Bobot } \\
\mathbf{x} \\
\text { Skor }\end{array}$ \\
\hline 1 & $\begin{array}{l}\text { Dukungan dana didapatkan dari P } \\
\text { ersekutuan Doa di Amerika, gereja, alumni } \\
\text { orang tua asuh dan dana BOS dari } \\
\text { pemerintah (siswa tidak membayar SPP) }\end{array}$ & 0,25 & 4 & 1,00 \\
\hline 2 & $\begin{array}{l}\text { Semangat juang/ komitmen dalam } \\
\text { pelayanan mengajar para guru yang tinggi } \\
\text { meskipun penghasilan sangat minim }\end{array}$ & 0,23 & 4 & 0,92 \\
\hline 3 & $\begin{array}{l}\text { Sarana prasarana lengkap dengan Lab yang } \\
\text { memadahi }\end{array}$ & 0,19 & 3 & 0,57 \\
\hline 4 & $\begin{array}{l}\text { Memiliki fasilitas panti asuhan bagi mereka } \\
\text { yang rumahnya jauh atau tidak dijaga orang } \\
\text { tuanya. }\end{array}$ & 0,17 & 3 & 0,51 \\
\hline 5 & $\begin{array}{l}\text { Guru memenuhi standard yaitu lulusan S1 } \\
\text { dan mengajar dibidang mereka masing- } \\
\text { masing, hanya terdapat satu guru yang tidak } \\
\text { bergelar sarjana. }\end{array}$ & 0,16 & 4 & 0,64 \\
\hline & \begin{tabular}{l} 
Total Skor \\
\hline
\end{tabular}
\end{tabular}

\begin{tabular}{|c|l|c|c|c|}
\hline No. & \multicolumn{1}{|c|}{ Kelemahan (Weaknesses) } & & \\
\hline 1 & $\begin{array}{l}\text { Jumlah siswa sedikit / tidak memenuhi } \\
\text { standar tiap tahunnya }\end{array}$ & 0,20 & 1 & 0,20 \\
\hline 2 & $\begin{array}{l}\text { Keterbatasan dana karena bergantung pada } \\
\text { donatur }\end{array}$ & 0,14 & 2 & 0,28 \\
\hline 3 & $\begin{array}{l}\text { Program unggulan belum ada karena } \\
\text { terhambat oleh dana }\end{array}$ & 0,12 & 1 & 0,12 \\
\hline 4 & $\begin{array}{l}\text { Promosi tidak merata, brosur selama ini } \\
\text { hanya disebarkan pada SD tertentu yang } \\
\text { memiliki alumni darii Sekolah tersebut }\end{array}$ & 0,12 & 2 & 0,24 \\
\hline 5 & $\begin{array}{l}\text { Akses Lokasi kurang strategis dan jarang } \\
\text { dijangkau transportasi umum }\end{array}$ & 0,12 & 3 & 0,36 \\
\hline 6 & $\begin{array}{l}\text { Kemampuan dasar peserta didik kurang } \\
\text { input) }\end{array}$ & 0,10 & 3 & 0,30 \\
\hline 7 & $\begin{array}{l}\text { Guru kebanyakan berstatus GTT yang } \\
\text { mengajar di sekolah lain }\end{array}$ & 0,10 & 2 & 0,20 \\
\hline 8 & \begin{tabular}{l} 
Kurangnya tenaga pengajar dalam \\
\hline
\end{tabular} & 0,10 & 2 & 0,20 \\
\hline
\end{tabular}




\begin{tabular}{|l|l|c|c|c|}
\hline & menangani ekstrakurikuler di sekolah & & & \\
\hline & Total Skor & 1 & & $\mathbf{1 , 9}$ \\
\hline & Total Skor Akhir (Kekuatan - Kelemahan) & & & $\mathbf{1 , 7 4}$ \\
\hline
\end{tabular}

Dari data pada tabel 2 dapat disimpulkan bahwa total bobot dikalikan skor pada faktor kekuatan adalah 3,64 sedangkan total bobot dikalikan skor pada faktor kelemahan adalah 1,9 sehingga skor akhir IFAS yaitu faktor kekuatan dikurangi faktor kelemahan adalah 1,74. Hal ini menunjukkan bahwa faktor kekuatan adalah faktor yang lebih dominan dibandingkan dengan faktor kelemahan. Oleh karena itu sekolah dapat mengoptimalkan kekuatan yang dominan yang dimiliki untuk mengatasi kelemahankelemahan yang ada.

Selanjutnya hasil analisis faktor eksternal sekolah meliputi peluang dan ancaman, pemberian bobot dan skor masing-masing faktor dan dilakukan perhitungan skor akhirnya hingga diperoleh matrik EFAS (eksternal Factors Analysis Summary) dapat dilihat pada tabel 3 berikut :

Tabel 3. Hasil Analisis Faktor Peluang dan Ancaman Matrik EFAS (External Factors Analysis Summary)

\begin{tabular}{|c|c|c|c|c|}
\hline \multirow{2}{*}{ No. } & Faktor-faktor Eksternal & \multirow{2}{*}{ Bobot } & \multirow{2}{*}{ Skor } & \multirow{2}{*}{$\begin{array}{c}\text { Total } \\
\text { Bobot } x \\
\text { Skor }\end{array}$} \\
\hline & Peluang (Opportunity) & & & \\
\hline 1 & $\begin{array}{l}\text { Memiliki Dua Sekolah Dasar di bawah yayasan } \\
\text { yang sama }\end{array}$ & 0,25 & 4 & 1,00 \\
\hline 2 & Terdapat dua panti yang mendukung sekolah ini & 0,20 & 4 & 0,80 \\
\hline 3 & $\begin{array}{l}\text { Kerjasama dan sosialisasi yang baik antara } \\
\text { sekolah-sekolah kristen }\end{array}$ & 0,20 & 3 & 0,60 \\
\hline 4 & Kepercayaan masyarakat masih cukup tinggi & 0,18 & 3 & 0,54 \\
\hline \multirow[t]{2}{*}{5} & $\begin{array}{l}\text { Dukungan dana dari pemerintah berupa Dana } \\
\text { BOS }\end{array}$ & 0,17 & 3 & 0,51 \\
\hline & Total Skor & 1 & & $\mathbf{3 , 4 5}$ \\
\hline No. & Ancaman (Threat) & & & \\
\hline 1 & $\begin{array}{lllll}\begin{array}{l}\text { Keterbatasan } \\
\text { donatur }\end{array} & \text { Dana yang bergantung pada } \\
\end{array}$ & 0,30 & 2 & 0,60 \\
\hline 2 & $\begin{array}{l}\text { Banyaknya sekolah-sekolah Negeri yang } \\
\text { bermunculan }\end{array}$ & 0,20 & 3 & 0,60 \\
\hline 3 & $\begin{array}{l}\text { Kurangnya pengawasan pemerintah terhadap } \\
\text { sistem PPDB }\end{array}$ & 0,18 & 3 & 0,54 \\
\hline 4 & $\begin{array}{l}\text { Tuntutan orang tua ke sekolah cukup tinggi } \\
\text { khususnya terhadap anak pindahan }\end{array}$ & 0,18 & 3 & 0,54 \\
\hline \multirow[t]{3}{*}{5} & $\begin{array}{l}\text { Latar belakang sosial orang tua kebanyakan dari } \\
\text { kalangan ekonomi bawah }\end{array}$ & 0,14 & 3 & 0,42 \\
\hline & Total Skor & 1 & & 2,70 \\
\hline & Total Skor Akhir (Peluang - Ancaman) & & & $\mathbf{0 , 7 5}$ \\
\hline
\end{tabular}


Perencanaan Strategi Bersaing Sekolah Dalam Meningkatkan Jumlah Peserta Didik Baru di Salah Satu Sekolah Swasta Salatiga | Dewa Made Dwi Kamayuda

Dari data pada tabel 3 dapat disimpulkan bahwa total bobot dikalikan skor pada faktor peluang adalah 3,45 sedangkan total bobot dikalikan skor pada faktor ancaman adalah 2,70 sehingga skor akhir EFAS yaitu faktor peluang dikurangi faktor ancaman adalah 0,75. Dari hasil analisis faktor eksternal tersebut diketahui bahwa sekolah memiliki beberapa peluang yang dapat dimanfaatkan untuk memberikan kontribusi dalam meningkatkan jumlah peserta didik baru.

Berdasarkan hasil analisis SWOT sekolah tersebut diketahui skor akhir IFAS adalah 1,74 sedangkan skor akhir EFAS adalah 0,75. Hasil analisis ini menunjukkan bahwa strategi berada di kuadran SO (strength oportunity) yang mendukung strategi agresif. Sehingga pihak sekolah dapat menggunakan kekuatan dari lingkungan internal sekolah dan meraih peluang yang ada pada lingkungan eksternal untuk meningkatkan jumlah peserta didik baru. Hasil analisis tersebut ditunjukkan melalui matrik SWOT pada Gambar 2 berikut:

\section{Gambar 2. Matriks Swot}

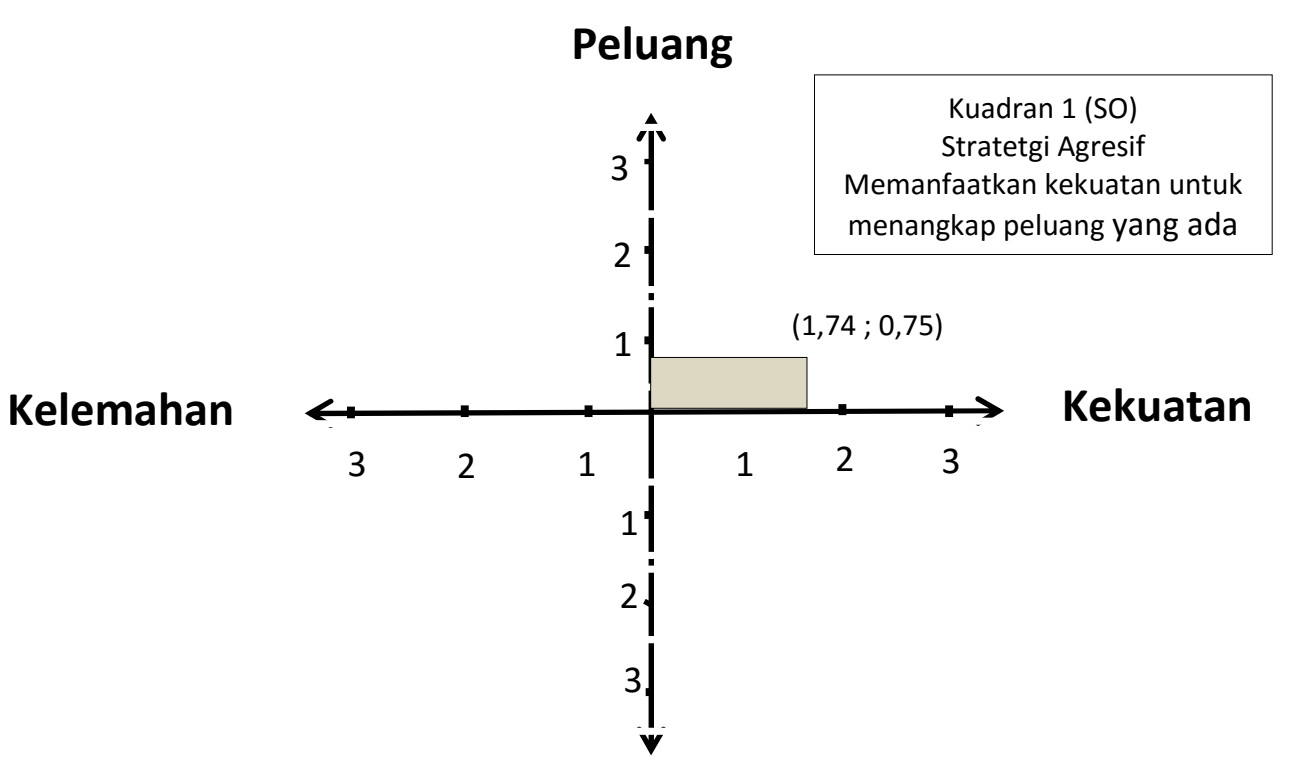

Ancaman (T)

Dari hasil analisis SWOT tersebut maka strategi bersaing sekolah yang perlu dibuat untuk meningkatkan jumlah peserta didik baru dapat dilihat pada tabel 4 berikut:

Tabel 4. Strategi Bersaing Berdasarkan Hasil Analisis SWOT

IFAS $\quad$ Strentghs (s)




\begin{tabular}{|c|c|c|c|c|c|}
\hline EFAS & $\begin{array}{l}\text { Semangat } \\
\text { juang/ } \\
\text { komitmen } \\
\text { dalam } \\
\text { pelayanan } \\
\text { mengajar } \\
\text { para guru } \\
\text { yang tinggi } \\
\text { meskipun } \\
\text { penghasilan } \\
\text { sangat minim }\end{array}$ & $\begin{array}{l}\text { nenuhi } \\
\text { yaitu } \\
1 \text { dan } \\
\text { mereka } \\
\text { lasing, } \\
\text { dapat } \\
\text { yang } \\
\text { gelar }\end{array}$ & $\begin{array}{l}\text { a } \\
\text { ana } \\
\text { ap } \\
\text { in } \\
\text { ang } \\
\text { dahi }\end{array}$ & $\begin{array}{l}\text { niliki } \\
\text { litas } \\
\text { ti } \\
\text { lan bagi } \\
\text { eka } \\
\text { g } \\
\text { ahnya } \\
\text { atau } \\
\text { k dijaga } \\
\text { g } \\
\text { ya. }\end{array}$ & $\begin{array}{l}\text { ukungan } \\
\text { ana } \\
\text { idapatkan } \\
\text { ari } \\
\text { ersekutuan } \\
\text { oa di } \\
\text { merika, } \\
\text { ereja, alumni } \\
\text { orang tua } \\
\text { suh dan dana } \\
\text { OS dari } \\
\text { emerintah }\end{array}$ \\
\hline $\begin{array}{l}\text { Memiliki } \\
\text { Sekolah D } \\
\text { bawah yay } \\
\text { sama }\end{array}$ & \multicolumn{5}{|c|}{$\begin{array}{l}\text { Strategi SO (Strenght - Opportunity) } \\
\text { 1. Meningkatkan kerjasama dan hubungan baik dengan masyarakat dengan } \\
\text { membuat program "pengabdian masyarakat" dan melibatkan siswa. } \\
\text { Program yang dapat dijalankan yaitu "students service community" ke } \\
\text { panti-panti, anak jalanan ataupun masyarakat sekitar. } \\
\text { 2. Membangun kerjasama dan kepercayaan dengan dua sekolah dasar di } \\
\text { bawah yayasan yang sama dengan melakukan sosialisasi secara rutin } \\
\text { untuk meyakinkan lulusan kedua sekolah dasar tersebut ikut dalam } \\
\text { penjaringan PPDB sekolah tiap tahunnya } \\
\text { 3. Meningkatkan prestasi sekolah dengan memaksimalkan SDM yang ada } \\
\text { dengan membentuk klub-klub prestasi baik dalam bidang akademis } \\
\text { maupun non akademis untuk mempersiapkan siswa ikut berkompetisi di } \\
\text { luar sekolah } \\
\text { 4. Memaksimalkan pembelajaran ekstrakurikuler melalui program } \\
\text { "students exhibition" dengan memanfaatkan sarana prasarana di } \\
\text { sekolah. Kegiatan ini juga dapat digunakan sebagai program "open } \\
\text { house" sekolah tiap tahunnya }\end{array}$} \\
\hline
\end{tabular}

Berdasarkan hasil analisis SWOT tersebut, maka strategi bersaing yang perlu

dibuat oleh sekolah sebagai upaya dalam memenangkan persaingan dan meningkatkan jumlah peserta didik baru adalah strategi diferensiasi dengan; (1) Meningkatkan kerjasama dan hubungan baik dengan masyarakat dengan membuat program "pengabdian masyarakat" dan melibatkan siswa. Program yang dapat dijalankan yaitu "students service community" ke panti-panti, anak jalanan ataupun masyarakat sekitar; 
(2) Membangun kerjasama dan kepercayaan dengan dua sekolah dasar di bawah yayasan yang sama dengan melakukan sosialisasi secara rutin untuk meyakinkan lulusan kedua sekolah dasar tersebut ikut dalam penjaringan PPDB sekolah tiap tahunnya; (3) Meningkatkan prestasi sekolah dengan memaksimalkan SDM yang ada dengan membentuk klub-klub prestasi baik dalam bidang akademis maupun non akademis untuk mempersiapkan siswa ikut berkompetisi di luar sekolah; (4) Memaksimalkan pembelajaran ekstrakurikuler melalui program "students exhibition" dengan memanfaatkan sarana prasarana di sekolah. Kegiatan ini juga dapat digunakan sebagai program "open house” sekolah tiap tahunnya; (5) Memaksimalkan potensi guru dengan mengadakan pelatihan-pelatihan ataupun mengikutkan guru-guru dalam kegiatan seminar atau workshop di luar sekolah untuk meningkatkan kinerja guru; (6) Memaksimalkan fasilitas panti asuhan dengan menawarkan kepada siswa-siswa dari luar kota saat sosialisai PPDB di sekolah-sekolah; (7) Mengadakan sosialisasi rutin kepada orang tua dan membuat program-program kebersamaan dengan siswa dan orangtua murid seperti "parents \& students funday" untuk meningkatkan kepercayaan dan kebersamaan dengan orang tua; (8) Melakukan sosialisasi rutin ke sekolah-sekolah negeri maupun swasta, gereja-gereja dan komunitas kristen yang ada sebelum melakukan perekrutan siswa baru.

\section{SIMPULAN DAN SARAN}

Berdarkan hasil analisis dan pembahasan, maka disimpulkan bahwa posisi sekolah berada pada kuadran SO, yaitu mendukung strategi agresif dengan menggunakan kekuatan dari lingkungan internal sekolah untuk meraih peluang yang ada pada lingkungan eksternal. Perencanaan strategi bersaing sekolah yang perlu dikembangkan adalah strategi diferensiasi, yaitu: (1) Meningkatkan kerjasama dan hubungan baik dengan masyarakat dengan membuat program "pengabdian masyarakat" dan melibatkan siswa. Program yang dapat dijalankan yaitu "students service community" ke pantipanti, anak jalanan ataupun masyarakat sekitar; (2) Membangun kerjasama dan kepercayaan dengan dua sekolah dasar di bawah yayasan yang sama dengan melakukan sosialisasi secara rutin untuk meyakinkan lulusan kedua sekolah dasar tersebut ikut dalam penjaringan PPDB sekolah tiap tahunnya; (3) Meningkatkan prestasi sekolah dengan memaksimalkan SDM yang ada dengan membentuk klub-klub prestasi baik dalam bidang akademis maupun non akademis untuk mempersiapkan siswa ikut berkompetisi di luar sekolah; (4) Memaksimalkan pembelajaran ekstrakurikuler melalui program "students exhibition" dengan memanfaatkan sarana prasarana di sekolah. 
Kegiatan ini juga dapat digunakan sebagai program "open house” sekolah tiap tahunnya; (5) Memaksimalkan potensi guru dengan mengadakan pelatihan-pelatihan ataupun mengikutkan guru-guru dalam kegiatan seminar atau workshop di luar sekolah untuk meningkatkan kinerja guru; (6) Memaksimalkan fasilitas panti asuhan dengan menawarkan kepada siswa-siswa dari luar kota saat sosialisai PPDB di sekolah-sekolah; (7) Mengadakan sosialisasi rutin kepada orang tua dan membuat program-program kebersamaan dengan siswa dan orangtua murid seperti "parents \& students funday" untuk meningkatkan kepercayaan dan kebersamaan dengan orang tua; (8) Melakukan sosialisasi rutin ke sekolah-sekolah negeri maupun swasta, gereja-gereja dan komunitas kristen yang ada sebelum melakukan perekrutan siswa baru.

Saran bagi kepala sekolah sebagai menajemen puncak adalah mengoptimalkan faktor kekuatan sekolah secara maksimal dan bertanggungjawab penuh terhadap pengelolaan dan peningkatan semua potensi dan sumber daya di sekolah sehingga visi, misi dan tujuan sekolah dapat tercapai. Selain itu kepala sekolah perlu melakukan evaluasi untuk melihat apakah program-program sekolah telah berjalan dengan baik atau tidak, dan dapat melihat kekurangan dan kelebihan dari program yang ada. Bagi pengurus yayasan perlu meningkatkan dukungannya dalam bentuk keterlibatan dalam membuat program-program sekolah sehingga program-program yang disarankan dapat segera diimplementasikan di sekolah. Bagi guru perlu untuk mengoptimalkan program ekstrakurrikuler di sekolah dengan membuat klub-klub prestasi baik akademik maupun non akademik, sehingga dapat melahirkan produk-produk maupun karya yang dapat disajikan dalam "school exhibition program" atau gelar karya sekolah.

\section{UCAPAN TERIMAKASIH}

Penulis mengucapkan terima kasih yang sebesar-besarnya kepada pihak-pihak yang mendukung penulisan paper ini. Kepada bapak Prof. Dr. Slameto dan bapak Dr. Bambang Ismanto, M.Si selaku dosen manajemen pendidikan mutu dan juga sekaligus pembimbing dalam penyelesaian paper ini. Kepada mahasiswa angkatan XXXIII Manajemen Pendidikan Universitas Kristen Satya Wacana untuk dukungan yang diberikan, dan kepada staff akademik yang membantu proses perizinan penelitian ke sekolah sehingga paper ini dapat terselesaikan tepat waktu.

\section{DAFTAR PUSTAKA}

David, F. R, 2008, Manajemen Strategis: Konsep, Edisi 10, Jakarta: Salemba 
Perencanaan Strategi Bersaing Sekolah Dalam Meningkatkan Jumlah Peserta Didik Baru di Salah Satu Sekolah Swasta Salatiga | Dewa Made Dwi Kamayuda

Edward Sallis. 2007, Total Quality Management in Education (Manajemen Mutu Pendidikan), YogyakartaL IRCISoD

Hitt, M. A., Ireland, R. D., Hoskisson, R. E. 1997, Manajemen Strategis: Menyongsong Era Persaingan Dan Globalisasi, Jakarta: Erlangga

Hunger, David. \& Wheelen, Thomas L. 2003, Manajemen Strategis, Yogyakarta: Andi

Lubis. 2004, Strategi Pemasaran Dalam Persaingan Bisnis, Universitas Sumatera Utara

Lupiyoadi, R. 2013, Manajemen Pemasaran Jasa (Praktik dan Teori), Jakarta: PT. Salemba Empat

Porter, M.S. 1992. Keunggulan Bersaing: Menciptakan dan Mempertahankan Kinerja Unggul, Jakarta: Erlangga

Porter. 2007, Strategy bersaing (Competitive Strategy): Teknik Menganalisis Industri dan Pesaing, Tangerang: Karisma Publishing Group

Putra, N. 2012. Research \& Development, Jakarta: PT Raja Grafindo Persada:

Rangkuti, F. 2013, Teknik Membedah Kasus Bisnis: Analisis SWOT, Jakarta: Gramedia Pustaka

Sagala, S. 2010, Manajemen Strategik dalam Peningkatan Mutu Pendidikan, Bandung: PT Alvabeta

Sugiyono. 2014, Metode Penelitian Manajemen, Alfabeta: Bandung

Trout, J \& Rivkin, S. 2001, Differentiate Or Die: Survival In Our Era Of Killer Competition, Jakarta: Erlangga

Purwanto, N. A. 2011, Strategi Bersaing Dalam Bisnis Pendidikan, Jurnal Manajemen Pendidikan, No. 01/Th VII/ April.

Sulistyawati, Sri. 2007, Strategi Perguruan Tinggi Dalam Menghadapi Persaingan Global. Jurnal Madani, Vol.8, No.3, Juni.

Wijaya, D. 2008, Pemasaran Jasa Pendidikan Sebagai Upaya untuk Meningkatkan Daya Saing Sekolah, Jurnal Pendidikan Penabur- No.11/Tahun ke-7/Desember. 